\title{
Health hazard of poorly regulated exposure during manufacture of cemented tungsten carbides and cobalt
}

\author{
J Howland Auchincloss, Jerrold L Abraham, Robert Gilbert, Michael Lax, \\ Paul K Henneberger, E R Heitzman, D J Peppi
}

\begin{abstract}
Forty two of 125 former workers in a factory in Syracuse, New York, which manufactured hard metal parts from tungsten carbide and cobalt, were studied by chest radiographs, spirometry, and plethysmographically determined lung volumes. The plant was closed in 1982 and the studies were performed in 1983-5. Recorded measurements of carbide dust concentrations were only mildly excessive by modern standards, but deceitful efforts to reduce the apparent concentration of dust were known to have occurred during an inspection by the Occupational Safety and Health Administration. Lung biopsies in four cases in the study and necropsy in one of the 83 cases not studied during life showed giant cell interstitial pneumonia and appreciable concentrations of tungsten carbide. This information indicates that exposure was substantial. Four workers had evidence of pulmonary fibrosis by chest radiographs; two of these workers had normal pulmonary function. Fourteen had abnormal pulmonary function, five of whom had a restrictive pattern, eight a pattern of air trapping, and one a combined pattern. Thus radiographic, or functional abnormalities, or both occurred in 16 of the 42 cases studied. No correlation with duration of exposure was established. Progressive clinically important disease (one fatal) has been found in four ex-workers, two in each of the restrictive and air trapping groups.

These findings suggest that poorly regulated dust concentrations in a hard metals factory possibly cause pulmonary abnormalities and sometimes severe illness.
\end{abstract}

State University of New York, College of Medicine, Pulmonary Section, 750 East Adams Street, Syracuse, New York 13210, USA

J H Auchincloss, J L Abraham, R Gilbert, M Lax, P K Henneberger, E R Heitzman, D J Peppi
The manufacture of cemented tungsten carbides containing cobalt presents a dual risk to the worker. The earliest description in $1940^{1}$ was based on changes in chest radiographs and therefore identified the risk of diffuse pulmonary disease, but by 1973 it became clear that there is a form of so called "hard metal disease" capable of causing cough and wheezing. ${ }^{2-4}$ Therefore, contemporary assessments of the impact of a period of exposure on the health of workers ${ }^{5}$ involve test procedures sensitive to both forms of injury. In a recent study of 1039 workers by Sprince et at abnormal radiographic findings suggesting diffuse disease occurred in $26(2 \%)$ workers, and work related wheeze occurred in 113 $(10 \%)$.

The distinctive feature of the present study is that it presents data on 42 of 125 workers employed in one plant in Syracuse, New York, during 1966-82 and studied in 1983-5. The plant was closed by the company in 1982. Although reliable dust measurements were not made, electron microprobe analysis of inorganic particulates in lung tissues of five subjects known to have been employed in the plant showed high amounts of tungsten in each case. This is taken to indicate substantial exposure.

\section{Material and methods}

Demand for hard metal machine tools expanded rapidly in the 1970s. Consequently the plant studied underwent major expansion in the 1960s and 1970s. The production process involved mixing raw materials including tungsten carbide, cobalt, tantalum, and traces of other metals. These metals were mixed in powdered form. Different grades of finished products required varying amounts of cobalt in the mix with proportions up to $24 \%$. Once mixed the materials were pressed into bars and then heated in a sintering furnace. The sintered pieces were machined to shape and reheated. After the reheating the hardened pieces were finished with various machining processes including grinding, lathing, and cutting.

As product demand increased, more machinery 
was installed and overtime was worked. Workers uniformly described the workplace as always visibly dusty. In 1979 the plant manager wrote to the division manager requesting that action be taken to reduce the amount of exposure to dust. There is no evidence that this request was heeded. In 1981 a band saw was inactivated during an inspection by the Occupational Safety and Health Administration (OSHA) and in 1985 the plant safety officer was convicted for making a false statement in this regard to the inspecting authorities. He received a prison sentence. Because of this evidence, the available air measurements probably underestimate what the workers actually experienced. Air samples for cobalt were taken at various locations in the plant in 1970 by the New York State Department of Labour and in 1981 by the Occupational Safety and Health Administration (OSHA; table 1). The highest concentrations occurred in the powder room where machinists worked in areas with breathing zone measurements ranging from $0 \cdot 14$ to $0.16 \mathrm{mg} / \mathrm{m}^{3}$. With the exception of the induction furnace and abrasive blasting areas in 1970, all the other locations had maximum concentrations of cobalt that exceeded the current OSHA permissible exposure limit of $0.05 \mathrm{mg} / \mathrm{m}^{3}$. In other plants of the same corporation values were as high as $2 \cdot 2 \mathrm{mg} / \mathrm{m}^{3}$. Because of the lack of a comprehensive industrial hygiene survey and the lack of detailed job histories it is not possible to go beyond the general statement that workers were overexposed. The only surrogate measure of dose available was duration of employment and this was incorporated into the analysis. For the five workers the lungs served as a final dust sampler.

Of an estimated total of 125 ex-employees, 40 men and two women (mean age 35 (SD 6.8), range 24-52) were interviewed and examined by the senior author during the years 1983-5. The study was done for both scientific interest and a legal proceeding. The subjects were recruited by a small group of exworkers and came of their own free will. They were not paid to participate. Although many had respiratory symptoms, some were asymptomatic. All were questioned on years of employment and smoking habits, but a questionnaire or other effort to maintain uniform procedure was not used because the purpose of the study was to obtain physiological and radiographic data for a legal action and this could lead to bias favouring exaggeration in the reporting of symptoms. In subsequent analyses, therefore, only duration of exposure and division into smoking and non-smoking categories were used. Detailed work histories before working in the hard metals plant were available for 13 of the 16 subjects in whom there were radiographic or physiological abnormalities, or both. One other worker was not examined clinically but was studied at necropsy after death from asphyxiation following a cerebrovascular accident.
Chest radiographs were taken during $1982-5$ and reports, or the original films themselves, were available. All 28 films available in 1989 were assembled and read by two chest radiologists without identification of the patient. To provide uniform analysis the chest radiographs were reanalysed by two radiologists without knowledge of the name or other features of the case. In one further case chest radiographs were unavailable but had previously been read by two persons, one a radiologist, as showing diffuse interstitial disease. No case was considered to show pulmonary fibrosis unless the films had been so described by two radiologists.

Spirometry and lung volumes plus airway resistance (constant volume body plethysmography) were by methods previously described from our laboratory, ${ }^{6}$ except that all spirometries were performed with the rolling seal spirometer and real time monitoring of flow volume loops. Predicted values for spirometry and lung volumes were obtained from the formulas of Crapo and associates, ${ }^{78}$ and $95 \%$ confidence intervals were calculated from their data. Based on the work of Pelzer and Thompson ${ }^{9}$ and our own work, ${ }^{6}$ the upper limit of normal for specific airway resistance was taken as $10 \mathrm{~s} \times \mathrm{cm} \mathrm{H}_{2} \mathrm{O}$ (specific conductance $0 \cdot 1$ ).

For classification of patients into groups spirometric and lung volume data were analysed for the occurrence of values outside the $95 \%$ confidence interval. The calculations of total lung capacity (TLC) and the ratio of residual volume to total lung capacity (RV/TLC) were selected as indicative of restrictive disease and obstructive disease respectively because they were the most sensitive and because each abnormality is well known in some patients with the specified disorder.

Quantitative analysis of lung particulate burden using an electron microprobe was performed by a previously described method. ${ }^{10}$

\section{Results}

Table 1 presents a summary of the data for the 42 cases. The ex-workers were divided into four groups based on the lung volumes. Group 1 (normal) had both normal TLC and RV/TLC. Group 2 (restrictive) had reduced TLC ( $95 \%$ confidence) but normal RV/TLC. Group 3 (air trapping) had normal TLC but raised values of RV/TLC (95\% confidence). "Group 4" (combined) was a single patient whose TLC was reduced and whose RV/TLC was increased. No statistically significant differences for age were found between groups 1,2 , and 3 .

The TLC\% predicted was considered to be the most specific available numerical test of restrictive disease. It did not correlate with radiographic findings, because, as shown in table 2 , radiographic evidence of fibrosis was found in four subjects, two in 
Table 1 Air measurements of cobalt in a hard metals factory ${ }^{\star}$

\begin{tabular}{lll}
\hline Date & Area in factory & $\begin{array}{l}\text { Range of } \\
\text { measurements } \\
\left(\mathrm{mg} / \mathrm{m}^{3}\right)\end{array}$ \\
\hline $1970 \dagger$ & Induction furnace, abrasive blasting & $0 \cdot 01-0 \cdot 03$ \\
& Powder room, general & $0 \cdot 02-0.09$ \\
$1981 \ddagger$ & Powder room, machinists & $0 \cdot 14-0 \cdot 16$ \\
& Lathe room, machinists & $0 \cdot 01-0 \cdot 1$ \\
& Powder room, machinists & $0 \cdot 027-0 \cdot 059$ \\
& Furnace room, inspector & $0 \cdot 014$ \\
\hline
\end{tabular}

OSHA Permissible exposure limit (eight hour time weighted average concentration) before $1989,0 \cdot 1$; since $1989,0.05 \mathrm{mg} / \mathrm{m}^{3}$.

*All samples were breathing zone samples except for the powder room; general samples done in 1970.

†Conducted by the New York State Department of Labour.

fConducted by OSHA.

the normal and two in the restrictive group. For the air trapping group, all of whom had increased values of RV/TC, only two had increased values of airway resistance and three had forced expiratory volume in one second $\left(\mathrm{FEV}_{1}\right) /$ vital capacity $(\mathrm{VC})$ values below $0 \cdot 7$.

We found no significant differences in years of exposure between any of the groups. Furthermore, within the restrictive group (group 2), there was no significant correlation between TLC and years of exposure $(r=0.08)$. Within the air trapping group (group 3) a significant correlation existed in smokers between years of exposure and RV/TLC $(r=0.73$, $t=4.9$ ) but the effect could not be separated from the effect of age because those with higher values tended to be older.

The 13 detailed work histories available failed to show additional occupations that might have caused either pulmonary fibrosis or airway obstruction. Two of these cases were in group 1 but had evidence of pulmonary fibrosis, and the other 11 were in groups 2 , 3 , or 4 . Therefore, work histories were available on 11 of the 13 cases with physiological impairment.

For one of the 42 patients chest radiographs were no longer available in 1989 but he was known to have shown shadows consistent with pulmonary fibrosis on the basis of more than one interpretation. In three further cases of pulmonary fibrosis the diagnosis was made from the concurrence of the two radiologists reading the 29 films. Pulmonary parenchymal abnormalities were seen in three more cases by one radiologist only. These cases were not entered as having pulmonary fibrosis.

\section{SYMPTOMS AND CLINICAL COURSE}

Follow up efforts by direct or telephone interview in 1989 were successful in reaching 18 subjects. From these data plus the original findings the following statements could be made: three of the five patients in group 2 had dyspnoea on exertion when first examined. In one case, previously reported, ${ }^{11}$ the progression of the disease since 1983 was dramatic and the patient died in 1990 . Two subjects in group 2 were free of dyspnoea both at the time of original study and at follow up in 1989. In group 3 (air trapping) one patient died after renal transplantation for renal insufficiency not believed to be related to hard metals disease. This decision was based upon the clinical course and findings at necropsy. Immune suppressive therapy and terminal pulmonary infection obscured any possible pathology related to industrial exposure, although an obviously raised lung tissue burden of tungsten particulate was documented. Another patient in group 3 had severe obstructive airway disease. Six of the eight subjects in group 3 stated that they had dyspnoea on exertion at the time of the original evaluation (1983-5), and the remaining two at the time of follow up (1989). In one case, a non-smoker, symptoms progressed, with loss of pulmonary function; $\mathrm{FEV}_{1}$ fell from 3.01 (66\% predicted) to $2 \cdot 21$ (48\% predicted) over a period of roughly three and a half years.

\section{PATHOLOGY AND MICROPROBE ANALYSIS}

Three of the patients had open lung biopsies (one also a necropsy), one had bronchoalveolar lavage and transbronchial biopsy, and one not examined clinically was studied at necropsy.

Lung tissue in four of the five cases showed interstitial fibrosis, mononuclear cell infiltrates, and unusual cannibalistic multinucleated giant cells in air spaces as seen in giant cell interstitial pneumonia. ${ }^{12}$ In the single case not showing these findings the lungs were characterised by severe diffuse alveolar damage

Table 2 Clinical data for 42 former workers with hard metals

\begin{tabular}{|c|c|c|c|c|c|c|c|c|c|c|c|c|c|c|}
\hline \multirow{3}{*}{$\begin{array}{l}\text { Group } \\
1 \\
2 \\
3 \\
4\end{array}$} & \multirow{3}{*}{$\begin{array}{l}\text { Functional pattern } \\
\text { Normal } \\
\text { Restriction } \\
\text { Obstruction } \\
\text { Restriction and } \\
\quad \text { obstruction }\end{array}$} & \multirow{2}{*}{$\begin{array}{l}\begin{array}{l}\text { No of } \\
\text { cases }\end{array} \\
28 \\
5 \\
8\end{array}$} & \multicolumn{2}{|c|}{$\begin{array}{l}\text { Age } \\
\text { Mean (SD) }\end{array}$} & \multicolumn{2}{|c|}{$\begin{array}{l}\text { Years } \\
\text { exposed } \\
\text { Mean (SD) }\end{array}$} & \multicolumn{2}{|c|}{$\begin{array}{l}\text { Non-smoker } \\
\text { No }(\%)\end{array}$} & \multicolumn{2}{|c|}{$\begin{array}{l}\text { Respiratory } \\
\text { symptoms } \\
\text { No (\%) }\end{array}$} & \multicolumn{2}{|c|}{$\begin{array}{l}\text { Pulmonary } \\
\text { fibrosis } \\
\text { No (\%) }\end{array}$} & \multicolumn{2}{|c|}{$\begin{array}{l}\text { Stay in } \\
\text { hospital } \\
\text { No (\%) }\end{array}$} \\
\hline & & & $\begin{array}{l}34 \\
39 \\
38\end{array}$ & $\begin{array}{l}6 \\
4 \\
9\end{array}$ & $\begin{array}{r}6 \\
7 \\
11\end{array}$ & $\begin{array}{l}5 \\
7 \\
6\end{array}$ & $\begin{array}{r}10 \\
2 \\
3\end{array}$ & $\begin{array}{l}(36) \\
(40) \\
(38)\end{array}$ & $\begin{array}{l}6 \\
3 \\
6\end{array}$ & $\begin{array}{l}(21) \\
(60) \\
(75)\end{array}$ & $\begin{array}{l}2 \\
2 \\
0\end{array}$ & $\begin{array}{r}(7) \\
(40) \\
(0)\end{array}$ & $\begin{array}{l}0 \\
1 \\
1\end{array}$ & $\begin{array}{l}(0) \\
(20) \\
(13)\end{array}$ \\
\hline & & 1 & 30 & & & & 0 & $(0)$ & 0 & $(0)$ & 0 & (0) & 0 & $(0)$ \\
\hline
\end{tabular}

^As determined by two radiologists. 
Table 3 Hard metals: lung histopathology and electron microprobe analysis

\begin{tabular}{lllllr}
\hline Case No & Source & Group & Exposure $(y)$ & Histopathology & $\begin{array}{c}\text { Concentration of tungsten } \\
\left.\text { particles } / \text { cm }^{3} \text { lung } \times 10^{6}\right)\end{array}$ \\
\hline 1 & OLB & 2 & 5 & GIP & 83 \\
2 & OLB & 2 & 17 & GIP & 765 \\
3 & Necropsy & NI & NI & GIP & 60 \\
4 & BAL and Trans & 3 & 19 & GIP & 1197 \\
5 & OLB and necropsy & 3 & 13 & Infection & 74 \\
\hline
\end{tabular}

GIP = Giant cell interstitial pneumonitis; OLB = open lung biopsy; BAL = bronchoalveolar lavage; Trans = transbronchial biopsy; $\mathrm{NI}=$ no information, patient not in clinical series; group $2=$ restrictive; group $3=$ obstructive; note: cases 1 and 2 were included in Fischbein et al. ${ }^{11}$

believed to have originated from immune suppression and pneumocystic pneumonia.

Table 3 presents the pathology and the results of tissue microprobe analysis.

\section{Discussion}

In the study of Sprince $e t a l$ the incidence of diffuse pulmonary disease was $2 \%$ and of work related wheeze $10 \%$. In the more recent study of MeyerBisch et $a l^{13} 56.8 \%$ of women in sintering and finishing workshops had spirographic abnormalities. In the present study pulmonary fibrosis in two cases from group 1 and all cases from groups $2-4$ gave a total of 16 or $38 \%$. If the 83 ex-workers not studied are considered, we have a minimum attack rate of 17 out of 125 or $14 \%$, and this figure makes no allowance for possible disease in these 83 subjects. The increase in the numerator stems from the knowledge that one of the $\mathbf{8 3}$ workers is known from necropsy studies to have had pulmonary fibrosis and a raised lung tissue burden of particulate containing tungsten. The detection of the apparently high attack rate in our series can be related to the use of body plethysmography analysis of pulmonary function as well as chest radiography. The $\mathrm{FEV}_{1} / \mathrm{VC}$ was reduced in only three of the eight subjects with raised RV/TLC. Reduced values of TLC were found in three subjects in the absence of radiographic evidence of pulmonary fibrosis. As it is unlikely that all of the 82 unstudied subjects were normal, the true attack rate must lie between $14 \%$ and $38 \%$. When such figures are combined with the potentially lethal character of the disease, its capability for progression after exposure as previously described ${ }^{11}$ and also found in this study, and the ever expanding use of hard metals in the manufacture of cutting tools of all sorts, this problem in occupational medicine deserves continued emphasis. In the present study we have the further problem of apparently heavy exposure, as discussed earlier. This may be the most distinctive feature of our study, as the reports of Sprince $e t a l$ and MayerBisch et $a l^{13}$ did not include cases of severe disease. Both groups of investigators appeared to have had excellent cooperation from the employer and only examined active workers.
In the absence of reliable workplace monitoring of exposure to cobalt for the workers in our study the analyses of lung tissues serves as documentation of their exposure. To put the findings of the microprobe analyses in perspective, the results can be compared with the results of similar analyses in the large data base described by Abraham et al, ${ }^{14}$ which is currently over 400 cases. All of their cases with concentrations of tungsten particles in the range seen in the present study had giant cell interstitial pneumonitis. Because cobalt itself was found in only $10 \%$ of cases, the tungsten particles serve as a marker of exposure. ${ }^{14}$

Does a relation exist between high exposure to cobalt and the severity of clinical disease in this study? The use of body plethysmography and chest radiology give a combined estimate of abnormalities that is substantial, and the tissue concentrations of tungsten carbide are also substantial. Yet most workers, some with prolonged histories of exposure, do not appear to have progressive disease or even detectable abnormality. Five of the eight patients with raised RV/TLC were smokers and this complicates the analysis. At this point we can only speculate that the severe pulmonary fibrosis in one worker, the moderately severe and progressive disease in three other workers, and the high attack rate are all related to poor control of dust concentration at the plant. We have attempted to build up a database retrospectively and the predominant evidence suggests that compliance of the plant with recognised standards of industrial hygiene was, at best, minimal. Although this approach illustrates the power of modern physiological techniques, chest radiography, and analysis of lung tissue, it does not substitute for industrial hygiene and is important mainly in showing that code enforcement was defective in Syracuse, New York, in the period 1970-80.

1 Jobs $\mathbf{H}$, Ballhausen C. Powdered metallurgy as a source of dust from the medical and technical standpoint. Vertravenargt 1940;5:142-8.

2 Bech AO, Kipling MD, Heather JC. Hard metal disease. $B r J$ Ind Med 1962;19:239-52.

3 Bruckner HC. Extrinsic asthma in a tungsten carbide worker. J Occup Med 1967;9:518-9.

4 Coates EO, Sawyer HJ, Rebuck JN, Kvale PA, Sweet LW Hypersensitivity bronchitis in tungsten carbide workers. Chest 1973;64:390. 
5 Sprince NL, Oliver LC, Eisen EA, Greene RE, Chamberlin RI. Cobalt exposure and lung disease in tungsten carbide production. Am Rev Respir Dis 1988;138:1220-6.

6 Gilbert R, Auchincloss JH Jr. The interpretation of the spirogram. How accurate is it for obstruction? Arch Intern Med 1985:1835-1839.

7 Crapo RO, Morris AH, Gardner RM. Reference spirometric values using techniques and equipment that meets ATS recommendations. Am Rev Respir Dis 1981;123:659-64.

8 Crapo RO, Morris AH, Clayton PD, Nixon CR. Lung volumes in healthy non-smoking adults. Bulletin de Physio-pathologie Respiratoire 1982;18:419-25.

9 Pelzer AM, Thompson ML. Effect of age, sex, stature, and smoking habits on human airway conductance. J Appl Physiol 1966;21:469-76.

10 Abraham JL, Burnett BR. Quantitative in situ analysis of inorganic particulate burden in tissue sections - an update. In: Ingram P, Shelburne J, Roggli Z, eds. Microprobe analysis in medicine, Hemisphere Publishing Corporation, 1989:111-31.

11 Fischbein AL, Abraham JL, Horowitz SF, et al. Hard metal disease: a multidisciplinary evaluation of two cases. New York State Journal of Medicine 1986;86:600-3.

12 Liebow AA. Definition and classification of interstitial pneumonias in human pathology. Prognosis in Respiratory Research 1975;8:1-33.

13 Meyer-Bisch C, Pharm QT, Massin N, et al. Respiratory hazards in hard metal workers: a cross sectional study. $\mathrm{Br} J$ Ind Med 1989;46:302-9.

14 Abraham JL, Burnett BR, Hunt A. Development and use of a pneumoconiosis data base of human pulmonary inorganic particulate burden in over $\mathbf{4 0 0}$ lungs. Scanning Microscopy 1991:5:95-108.

Accepted 17 February 1992

\section{Vancouver style}

All manuscripts submitted to the $B r J$ Ind Med should conform to the uniform requirements for manuscripts submitted to biomedical journals (known as the Vancouver style).

The $\mathrm{Br} J$ Ind Med, together with many other international biomedical journals, has agreed to accept articles prepared in accordance with the Vancouver style. The style (described in full in $\mathrm{Br}$ Med J, 24 February 1979, p 532) is intended to standardise requirements for authors.

References should be numbered consecutively in the order in which they are first mentioned in the text by Arabic numerals above the line on each occasion the reference is cited (Manson ${ }^{1}$ confirmed other reports ${ }^{2-5} \ldots$. . In future references to papers submitted to the $\mathrm{Br} J$ Ind Med should include: the names of all authors if there are six or less or, if there are more, the first three followed by $e t$ al; the title of journal articles or book chapters; the titles of journals abbreviated according to the style of Index Medicus; and the first and final page numbers of the article or chapter.

Examples of common forms of references are:

1 International Steering Committee of Medical Editors. Uniform requirements for manuscripts submitted to biomedical journals. Br Med J 1979;1:532-5.

2 Soter NA, Wasserman SI, Austen KF. Cold urticaria: release into the circulation of histamine and eosino-phil chemotactic factor of anaphylaxis during cold challenge. N Engl J Med 1976;294:687-90.

3 Weinstein L, Swartz MN. Pathogenic properties of invading micro-organisms. In: Sodeman WA Jr, Sodeman WA, eds. Pathologic physiology: mechanisms of disease. Philadelphia: W B Saunders, 1974:457-72. 